\title{
Students' Perceptions of Online Learning: A Comparative Study
}

\author{
Karl L. Smart and James J. Cappel \\ Central Michigan University, Mount Pleasant, MI, USA
}

karl.smart@cmich.edu james.cappel@cmich.edu

\section{Executive Summary}

In search of better, more cost effective ways to deliver instruction and training, universities and corporations have expanded their use of e-learning. Although several studies suggest that online education and blended instruction (a "blend" of online and traditional approaches) can be as effective as traditional classroom models, few studies have focused on learner satisfaction with online instruction, particularly in the transition to online learning from traditional approaches. This study examines students' perceptions of integrating online components in two undergraduate business courses where students completed online learning modules prior to class discussion. The results indicate that participants in an elective course rated the online modules significantly better than those in a required course. Overall, participants in the elective course rated the online modules marginally positive while those in the required course rated them marginally negative.

These outcomes suggest that instructors should be selective in the way they integrate online units into traditional, classroom-delivered courses. This integration should be carefully planned based on learner characteristics, course content, and the learning context. For most participants of the study (83 percent), this was their first experience completing an online learning activity or module. In addition, the largest dissatisfaction factor reported among the participants was the time required to complete the online modules. Future research is encouraged to explore: (1) how previous experience with technology and online learning affects students' attitudes towards and success with e-learning; and (2) the effects of interspersing online units that are considerably shorter in length into the traditional classroom model. This additional research can provide greater insight into which factors promote e-learning success.

Keywords: E-learning, Online learning, Web-based learning, Blended Learning, Learner satisfaction

\section{Introduction}

E-learning has grown tremendously over the past several years as technology has been integrated

Material published as part of this journal, either on-line or in print, is copyrighted by the publisher of the Journal of Information Technology Education. Permission to make digital or paper copy of part or all of these works for personal or classroom use is granted without fee provided that the copies are not made or distributed for profit or commercial advantage AND that copies 1) bear this notice in full and 2) give the full citation on the first page. It is permissible to abstract these works so long as credit is given. To copy in all other cases or to republish or to post on a server or to redistribute to lists requires specific permission and payment of a fee. Contact Editor@JITE.org to request redistribution permission. into education and training. "Elearning" may be defined as instruction delivered electronically via the Internet, Intranets, or multimedia platforms such as CD-ROM or DVD (Hall, 2003; O’Neill, Singh, \& O’Donoghue, 2004). Since many users today have access to direct Internet connections, e-learning is often identified with web-based learning (Hall, 2003). Many writers refer to "elearning," "online learning," and 
"web-based learning" interchangeably, an approach that will be taken in this paper. E-learning can be implemented in a variety of ways, such as through the use of self-paced independent study units, asynchronous interactive sessions (where participants interact at different times) or synchronous interactive settings (where learners meet in real time) (Ryan, 2001).

Estimates suggest that the amount of money U.S. companies spent on the IT-based delivery of training grew from $\$ 3$ billion in 1999 to $\$ 11$ billion in 2003 (Koprowski, 2000). In addition, the worldwide market for e-learning is projected to be more than $\$ 18$ billion by the end of 2005 (Moore, 2001), with some organizations projecting that over half of their training and education will be delivered electronically over the next five years (Gold, 2003). Colleges and universities also continue to increase their web-based course offerings to appeal to audiences such as working adults who otherwise have limited access to higher education (Haugen, LaBarre, \& Melrose, 2001; Liaw \& Huang, 2002; McEwan, 2001) and as curricular and organizational changes demand new ways of delivering education to individuals (O'Neill, Singh, \& O'Donoghue, 2004; Schleede 1998). Projections suggest online offerings will continue to increase significantly in educational as well as corporate settings in years to come (Meyen, Aust, Gauch, Hinton, \& Isaacson, 2002).

Although e-learning (and various blended approaches that integrate online components into traditional classes) continues to grow rapidly, it still remains at an early stage of development. Consequently, developers and deliverers of online learning need more understanding of how students perceive and react to elements of e-learning (since student perception and attitude is critical to motivation and learning) along with how to apply these approaches most effectively to enhance learning (Koohang \& Durante, 2003). This research assesses the perceived effectiveness of the use of online learning modules in two undergraduate information systems (IS) business courses, an elective course and a required course. The results raise important considerations about using online learning for business and IS instruction.

\section{Literature Review}

What we know about learning is an important starting point for exploring the use of technology and the design and success of online and blended learning. The basis of effective online learning is comparable to the foundation of effective learning in general. Among the many theories surrounding how people learn, this paper focuses on three aspects of learning, which in turn are tied to the use of the online learning components integrated in the two courses of the study.

Learning theory suggests that learning is promoted or enhanced (1) when students are actively involved in the learning, (2) when assignments reflect real-life contexts and experiences, and (3) when critical thinking or deep learning is promoted through applied and reflective activities (Bransford, Brown, \& Cocking, 2000; Driscoll 2002). Each of these aspects of learning are briefly reviewed, with a subsequent discussion of how the online learning components integrated in the two courses were chosen with these dimensions in mind.

Numerous studies have demonstrated that a student's active involvement in the learning process enhances learning, a process often referred to as active learning (Benek-Rivera \& Matthews, 2004; Sarason \& Banbury, 2004). Simply stated, active learning involves "instructional activities involving students in doing things and thinking about what they are doing" (Bonwell \& Eisen, 1991, p. 5). Interactive instruction or "learning by doing" has been found to result in positive learning outcomes (Picciano, 2002; Watkins, 2005). Because many new technologies and webbased activities are interactive, online coursework has the potential to create environments where students actively engage with material and learn by doing, refining their understanding as they build new knowledge (Johnston, Killion \& Omomen, 2005; Pallof \& Pratt, 2003). As Driscoll (2002) observes, "When students become active participants in the knowledge construction proc- 
ess, the focus of learning shifts from covering the curriculum to working with ideas. And using technology tools 'to think with' facilitates working with ideas and learning from that process" (also see Scardamalia 2002).

In addition to active involvement, students better understand and apply material when problems and situations are set in the context of real world issues and situations (Eble, 1988). Authentic situations and scenarios can provide a stimulus for learning, creating greater student motivation and excitement for learning, representing and simulating real-world problems and contexts, providing an important structure for student thinking (Quitadamo \& Brown, 2001). Emphasizing authentic tasks in context rather than abstract out-of-context activities creates a greater likelihood of learning (Driscoll \& Carliner, 2005). Technology and online instruction can facilitate learning by providing real-life contexts to engage learners in solving complex problems (Duffy \& Cunningham, 1996; Honebein, 1996).

The use of real-world situations has the potential to promote deep learning through the development of critical thinking skills. Critical thinking involves the active and skillful analysis, synthesis, and application of information to unique situations (Scriven \& Paul, 2004). Learning retention and performance improves as students are required to apply what they have learned and then reflect upon the learning (Bereiter \& Scardamalia, 1989; Bransford, Brown, \& Cocking, 2000). Again, online instruction has the potential to provide opportunities to promote reflective thought and deep learning through realistically integrating and applying principles learned. Online instruction, such as a simulation, thrusts learners into a learning experience, increasing engagement and providing activities that actively engage learners to analyze, synthesize, and evaluate information while constructing knowledge (Driscoll \& Carliner, 2005).

Built upon a foundation of learning theory, e-learning can potentially provide many important payoffs. To learners, online instruction offers the flexibility and convenience to complete learning units when and where a learner desires. Additionally, online education has been used to reduce costs and to provide an efficient, standardized way to deliver content (McDonald, 1999-2000; "Elearning," 2003; "The Pay-offs," 2003).

In addition to potential cost savings, e-learning has pedagogical potential beyond traditional methods related to the principles of learning discussed. For instance, multimedia capabilities can be used with learning exercises that allow learners to apply concepts realistically. Or, animation can help demonstrate concepts and events difficult to portray in traditional classes, which, in turn, can facilitate a more accurate communication of important ideas. E-learning can deliver "new" information not contained in traditional sources, effectively reinforcing other course information through offering examples, explanations, assessments, and exercises. In this way, online instruction can potentially enhance learning compared to what can be accomplished using a classroomonly approach (McEwen, 1997).

However, there are also potential disadvantages or limitations of online learning. For example, one study concluded that asynchronous e-learning was not effective as a standalone method to deliver technical training for information technology professionals Learners in the study commented that e-learning eliminates classroom interaction time, where a significant amount of "real learning" takes place as users assimilate information, utilize software, apply knowledge to problem solving, and interact with the instructor and other learners (Laine, 2003).

Other potential problems of e-learning that have been identified in previous research include a sense of learner isolation (Brown, 1996); learner frustration, anxiety, and confusion (Hara \& Kling, 2000; Piccoli, Ahmad, \& Ives, 2001); higher student attrition rates (Frankola, 2001; Laine, 2003; Ryan, 2001); the need for greater discipline, writing skills, and self-motivation; and the need for online users to make a time commitment to learning (Golladay, Prybutok, \& Huff, 2000; Serwatka, 2003). 
Based on these considerations, some research has stressed the importance of using a "blended learning" approach (Davis, 2000; Koohang \& Durante, 2003). Blended learning is a hybrid instructional approach that combines elements of e-learning with the traditional classroom environment (Rubenstein, 2003; Ward \& LaBranche, 2003). It involves starting with learning objectives and then selecting the best combination of delivery methods to meet those objectives (Ward \& LaBranche, 2003). In some situations, blended learning may involve students completing online units prior to meeting to ensure they share a common foundation of knowledge. This allows class sessions to go into greater depth with application exercises and problem solving. Alternatively, e-learning elements can be used after class meetings to maintain an ongoing dialogue among a community of participants about course-related topics through chats or discussion board postings. Other blended learning options may use a combination of pre-class and post-class elearning components.

In 1998, Beller and Or noted that very little research attention has been devoted to web-based education and learning. Although additional research has been conducted since that time, many unexamined issues remain (O'Neill, Singh, \& O'Donoghue 2004, Piccoli et al., 2001). Specifically, Wang (2003) found that research seldom addresses the element of learner satisfaction with e-learning. Yet, as the use of e-learning and blended learning continues to expand significantly in higher education and business environments, we must gain an improved understanding of where, when, and under what circumstances online and blended learning can be applied most effectively as well as how it can best be implemented.

This need to better understand how to implement and use online instruction leads to the first research question of this study: What are students' perceptions of online learning components within a traditional, classroom-delivered course? The outcomes considered for this measure include user satisfaction and participants' views of various other aspects of the e-learning environment.

Secondly, various researchers have shown that learning in an online environment requires a significant amount of discipline and self-motivation (Golladay et al., 2000; Serwatka 2003). This is particularly true where the online units are completed as independent, self-study units, as opposed to users interacting as part of a community of online users. Experience has shown that completing online units requires a significant investment of time by users. In specific terms, participants in this study required on average between seven and eight hours to complete the two online learning units - a commitment some students are likely to be more willing to make than others.

As research suggests, learner motivation is one of the key factors affecting student performance and learning, particularly online learning success (Cole, Field \& Harris, 2004; Ryan, 2001). Among the most important factors that influence the motivation of students are students' interest in the content and students' perceived relevance of the course - do students have an interest in the content and do they believe it applies to them or their future jobs? (Adler, Milne \& Stablein ,2001; Benbunan-Fich \& Starr, 2003; Brass, 2002; Burke \& Moore, 2003; Geiger \& Cooper, 1996). If students perceive some benefit to their learning (through either a personal interest in or an application of content), they will likely be more motivated to perform well. As McKeachie (2002, p.19) observes, "Students who are motivated to learn will choose tasks that enhance their learning, will work hard at those tasks, and will persist in the face of difficulty in order to attain their goals."

In comparing students, we were interested to see if differences existed in students' attitudes about the learning modules in a required course versus an elective course. Since students in elective courses engage in some type of self-selection when enrolling for such a course (presumably based, in part, on interest or perceived relevance), we were interested to see if the perceptions of these students differed from students in the required course-leading to the second research ques- 
tion of this study: Do students' perceptions of online learning components differ between those enrolled in an elective course versus those enrolled in a required course?

\section{Methodology}

The data for this study are based on students' experiences taking an online learning unit offered by the Information Technology Training Initiative (ITTI) of the Michigan Virtual University (MVU) at its website, www.mivu.org. The MVU is a private, not-for-profit Michigan corporation that began in 2001 to deliver more than 700 web-based, self-paced independent study learning units to the Michigan workforce in the United States. "Qualified users" (enrolled students, faculty, and staff at Michigan high schools, community colleges, colleges, and universities) could access ITTI courses free of charge until recently, when government budget cuts in the state of Michigan forced the MVU to begin charging users to take courses. The study reported on in this paper was conducted prior to the implementation of charges to student users.

The online courses offered by the ITTI, which are also referred to as "learning units" in this paper, were developed by NETg, a leading vendor of online training products. The courses provide hands-on learning experiences, and include the use of graphics, sound, video, and simulations. Each course is divided into several modules. At the end of each module, students take a mastery test to track their progress and reinforce their understanding of the skills covered. Each online learning unit is designed to be the equivalent of about four to six hours of classroom training.

For this study, students were enrolled in one of two courses at a medium-sized Midwestern university in the United States, (1) a required IS business course (Business Communications - a class typically taken by third-year (junior) and fourth-year (senior) students) or (2) an elective course (Business Computer Graphics - a class generally taken by second-year (sophomore) and thirdyear (junior) students). For clarity and ease of reference, the Business Communication and Business Computer Graphics classes will be referred to as the "required course" and the "elective course," respectively, in the remainder of this paper.

In both courses, student teams were organized at the beginning of the semester and maintained for the duration of the course. The instructor made team assignments based on gender, class ranking, and a short content assessment in an attempt to create heterogeneous groups. Research-based guidelines for creating optimal teams were followed (see Ancona \& Caldwell, 1992; Gruenfeld \& Hollingshead, 1993; Hackman, 1990; Schneidel \& Crowell, 1979; Watson, Kumar, \& Michaelsen, 1993). The teams frequently engaged in content-related discussions and completed a variety of short tasks as a group. In addition, the teams completed three group exams and a major group project in both classes during the semester.

During the initial two weeks of the respective courses, part of the course instruction included exploring group processes and establishing team expectations. Class time was spent addressing the stages of team development (i.e., forming, storming, norming, performing - see Tuckman, 1965), along with getting acquainted activities to promote team cohesion. The focus on communication emphasizes the critical role of communication in IS curriculum and, subsequently, in the workplace (Miller \& Luse, 2004). Half-way through the semester, both classes were assigned to complete two ITTI learning units entitled "Team Management: High Performance Teams" and "Virtual Teams: Communicating Effectively."

The purpose of these two learning units was to review principles of effective teams at a point in the semester after group members had gained experience working with one another and had typically encountered some behavioral and communication challenges. In addition, the learning units covered new information (not previously addressed in class) about virtual teams, conflict in teams, and effective communication. This new content was targeted to prepare students for a major team project in which virtual communication tools (both synchronous and asynchronous) 
would be widely used. Specifically, the Team Management learning unit reviewed principles of team roles and goals (reinforcement of previously covered material) in addition to new information on understanding and resolving team conflict, motivating others, and building team support. The Virtual Teams unit reviewed concepts related to effective listening and developing trust along with material on overcoming communication problems and using technology to communicate.

The e-learning units each consisted of a few carefully focused objectives presented in shorter modules. Each objective was developed with instructional material, including multimedia supported text. Typically, each objective was presented with a series of screens containing information as text and graphics. An accompanying audio track was included that repeated the text for those wishing to listen to the narrative in addition to reading the text. Short video-clips demonstrating certain principles in real-life settings were also integrated. At the end of each module, students were required to take a short multiple-choice online assessment to evaluate their understanding of key concepts within the module. The multiple choice questions were primarily basic knowledge and comprehension questions based on the content presented. This assessment was saved and later printed as verification of a student's completing the learning unit.

In addition, each learning unit ended with a simulation, a scenario based on a real-life work situation. These scenarios pushed students into the higher levels of reasoning and thinking, asking them to analyze, synthesize, and evaluate situations (higher level critical thinking skills) using the information covered in the units. For example, the simulation following the Team Management module consisted of a video replicating a meeting of a work team consisting of three individuals. A problem was posed to the work team (of which the student was to consider himself or herself a part of). Short video clips would present the scenario that demonstrated members of the team responding to issues. Then, the student who was completing the simulation was posed with a series of different responses or actions to take in response to the scenario. From the alternatives, students had to select a response they thought would be appropriate when dealing with issues presented in the video. Depending upon the action students selected, the simulation would progress in different ways. The students' choices would resolve problems if the choice was appropriate or cause additional problems if inappropriate (based upon the principles covered in the learning unit), with the continuation of the scenario reflecting the choice of the student. At the end of the simulation, the student's choices were evaluated based on the principles covered in the module, with feedback given to reinforce appropriate reactions or choices and suggestions for different choices given that would result in a better approach to the presented scenario.

The online components and accompanying assignment were carefully selected to reinforce the three learning dimensions identified and discussed earlier in this paper-an opportunity for active learning, a real-world context, and a chance to use critical thinking skills. Working through the modules and simulations required active interaction by students. Additionally, the content and context of the modules was real-world based, using examples typical of the workplace students could find themselves in upon graduation. The simulations (along with the follow-up activity in class) were designed to create reflective thinking on teams as well as promote critical thinking skills through the application of principles about teams and communication. Pedagogically, the online units enhanced part of the core content of the courses along with underscoring the foundational learning theory used by the instructor in the design of the courses.

Various issues - such as motivating the team, dealing with conflict, summarizing issues, or striving for agreement-were covered in the simulations. At the end of the simulation, students were provided with a summary of the decisions they made, detailing the issue presented and the result of their decisions. If potentially better decisions could have been made, these decisions with their expected consequences were also reviewed. In this manner, students had an opportunity to dem- 
onstrate higher-level critical thinking skills by applying concepts and principles learned from the learning units.

Students were given the equivalent of two full class sessions (approximately four hours) and no additional homework to work through the learning units during a two-week period. In the session prior to the work sessions, students were guided through registering at the MVU site and shown how to access the learning units. A follow-up discussion reviewing content from the learning units was held in each class on the due date for completing the learning units. In the class session, students engaged in a dyadic "think-pair-share" exercise. Students first took about five minutes to individually respond to the following:

(1) Briefly write down 3-4 things you think are significant about teams based on the material you covered in the MVU learning units

(2) From your experience, what do you see are causes of conflict in teams? How do you typically deal with conflict in groups? From what you learned in the learning units, how might you improve your dealing with conflicts?

The participants then paired up with a fellow class member for a few minutes to share their responses. Afterwards, the main points of the learning units were reviewed through discussion with the entire class, with an emphasis of how concepts had applied or could apply to the teams students were now a part of in the class. At the end of the session, students submitted a printed summary of their learning unit assessments (results from the multiple choice tests and the scenario) and their responses to the in-class exercise. A certain number of points were allotted for the online modules; those students who completed the online modules and submitted the results received full points or marks for the online assignment, which figured as a percentage of their overall grade for the course.

A survey was administered to students anonymously during the first class meeting after class discussion of the online learning units. The survey instructed participants to provide honest feedback about their experiences with this learning approach. Thirty six (of 40 enrolled) in the required course and eighteen (of 26 enrolled) in the elective course completed the survey. One response had to be eliminated since that student reported no usage of either online course. The results of the study, therefore, are based on fifty-three responses, which represent more than 80 percent of the total students enrolled in both courses. T-tests or chi-square tests were applied as appropriate to test for statistical significances between various measures in this study. Two open-ended survey questions were also included to solicit respondents' opinions about the online courses' strengths and limitations, and recommendations for improvement.

\section{Participants}

The characteristics of the participants are summarized in Table 1. As indicated, the overall sample was fairly evenly distributed by gender (54 percent females and 46 percent males). The participants consisted of 58 percent $4^{\text {th }}$ year students (classified as seniors in the United States), 39 percent $3^{\text {rd }}$ year students (juniors), and 4 percent $2^{\text {nd }}$ year students (sophomores), and most ( 94 percent) were business majors. Chi-square tests revealed that subjects in the elective course had greater awareness of the MVU prior to this study, they were more likely to have previously completed an MVU learning unit, and they consisted of significantly fewer business majors than subjects in the required course. There were no significant differences between subjects in the two courses based on gender, student rank, and prior experience completing a web-based course at a site other than the MVU. 
Table 1. Participant Characteristics

\begin{tabular}{|c|c|c|c|c|}
\hline & $\begin{array}{l}\text { Required } \\
\text { course }\end{array}$ & $\begin{array}{l}\text { Elective } \\
\text { course }\end{array}$ & $\begin{array}{l}\text { All } \\
\text { Subjects }\end{array}$ & $\begin{array}{l}X^{2} \text { Test } \\
\text { Results }\end{array}$ \\
\hline \multicolumn{5}{|l|}{ Gender: } \\
\hline Male & $50.0 \%$ & $38.9 \%$ & $46.2 \%$ & \multirow[t]{2}{*}{.444} \\
\hline Female & $50.0 \%$ & $61.1 \%$ & $53.8 \%$ & \\
\hline \multicolumn{5}{|l|}{ Student Rank: } \\
\hline $4^{\text {th }}$ Year (Senior) & $47.1 \%$ & $77.8 \%$ & $57.7 \%$ & \multirow[t]{3}{*}{.063} \\
\hline $3^{\text {rd }}$ Year (Junior) & $50.0 \%$ & $16.7 \%$ & $38.5 \%$ & \\
\hline $2^{\text {nd }}$ Year (Sophomore) & $2.9 \%$ & $5.6 \%$ & $3.8 \%$ & \\
\hline \multicolumn{5}{|l|}{ Major: } \\
\hline Business & $100.0 \%$ & $83.3 \%$ & $94.2 \%$ & \multirow[t]{2}{*}{$.014 *$} \\
\hline Non-Business & $0.0 \%$ & $16.7 \%$ & $5.8 \%$ & \\
\hline \multicolumn{5}{|c|}{ Prior awareness of the MVU } \\
\hline Yes & $0.0 \%$ & $22.2 \%$ & $7.5 \%$ & \multirow[t]{2}{*}{$.004 * *$} \\
\hline No & $100.0 \%$ & $77.8 \%$ & $92.5 \%$ & \\
\hline \multicolumn{5}{|c|}{$\begin{array}{l}\text { Prior experience completing an MVU } \\
\text { course }\end{array}$} \\
\hline Yes & $0.0 \%$ & $11.1 \%$ & $3.8 \%$ & \multirow[t]{2}{*}{$.047 *$} \\
\hline No & $100.0 \%$ & $88.9 \%$ & $96.2 \%$ & \\
\hline \multicolumn{5}{|c|}{$\begin{array}{l}\text { Prior experience completing a web-based } \\
\text { course at another site }\end{array}$} \\
\hline Yes & $14.7 \%$ & $22.2 \%$ & $17.3 \%$ & \multirow[t]{2}{*}{.498} \\
\hline No & $85.3 \%$ & $77.8 \%$ & $82.7 \%$ & \\
\hline
\end{tabular}

$* \mathrm{p}<.05 ; * * \mathrm{p}<.01 ; * * * \mathrm{p}<.001$

\section{Results}

The findings of the survey are presented below. Most evaluation measures focus on subjects' perceptions of the online units.

\section{Overall Satisfaction and Subjects' Perceptions of the Online Learning Units}

Table 2 presents several important measures of participants' reactions to completing the online learning units. Overall, as indicated by the summary (composite) means presented at the bottom of the table and the use of a seven-point response scale, subjects in the elective course rated the online modules marginally positive (4.67) while those in the required course rated them marginally negative (3.70). For five of six measures in Table 2, students in the elective course rated the online learning units significantly higher than students in the required course, while for the additional measure there was no observed difference. 
Table 2. Subjects' Perceptions of the Online Learning Units

$\begin{array}{llll}\begin{array}{l}\text { Required } \\ \text { Course }\end{array} & \begin{array}{l}\text { Elective } \\ \text { Course }\end{array} \\ \text { Mean SD } & \text { Mean } \quad \text { SD } & \text { p }\end{array}$

Overall satisfaction with the learning units \#

Using the online units was an effective way to learn about the assigned topics

Using the online learning units was fun

$1.14 \quad .000 * * *$

An online learning unit assignment similar to this should be used in this course in the future

Completing the online units did not take more time and effort than it was worth (rc)

Questions asked in the online units were not too difficult (rc)

Composite measure

(mean of means)

\# This item is based on the seven-point scale: $7=$ extremely satisfied, $6=$ moderately satisfied, $5=$ slightly satisfied, $4=$ don't know/no opinion, $3=$ slightly dissatisfied, $2=$ moderately satisfied, and $1=$ extremely dissatisfied.

The other items are based on the seven-point scale: $7=$ strongly agree, $6=$ moderately agree, $5=$ slightly agree, $4=$ don't know/no opinion, $3=$ slightly disagree, $2=$ moderately disagree, and $1=$ =strongly disagree.

(rc) Indicates a reverse coded question. These items were asked in a "negative" way in the survey, but they are presented in this table in an opposite (positive) direction to facilitate response comparison across items.

$* \mathrm{p}<.05 ; * * \mathrm{p}<.01 ; * * \mathrm{p}<.001$

For the first measure, overall satisfaction, subjects rated the two online units they completed separately in the survey. Since statistical tests later revealed no significant differences across the units on this measure, for clarity and simplicity, the first item in Table 2 shows the pooled satisfaction ratings for both units. As shown, students in the elective course had a significantly higher mean satisfaction rating (5.67) than subjects in the required course (4.25).

Table 2 also indicates that students in the elective course rated the online learning units significantly higher in terms of being "an effective way to learn" and "fun," and they were significantly 
more in favor of using the online units again in this course in the future. To minimize response bias, some survey questions were stated negatively. For example, in the survey, the fifth item in Table 2 was worded, "Completing the online units took more time and effort than it was worth," and the sixth item read, "Questions asked in the online units were too difficult." For reporting and analysis purposes, these items were reverse-coded and stated in a positive direction in Table 2 to allow easier comparison to the other responses. Thus, the reported averages for the fifth item (which are both less than 4 on the seven-point scale) indicate that on average, participants enrolled in both courses agreed that the online experience "took more time and effort than it was worth." However, students in the required course showed a significantly stronger level of agreement with this statement than those in the elective course.

\section{Ratings of Specific Learning Unit Dimensions}

Participants also rated the online learning units on several specific measures using a five-point scale, ranging from 5 for "excellent" to 1 for "extremely unsatisfactory." Again, while the two online units were rated separately on these dimensions, statistical tests revealed no significant differences across the units so Table 3 shows the pooled results of the ratings for both units. For all five measures, the mean ratings of students in the elective course were significantly higher than those for students in the required course, which is consistent with the results presented in Table 2.

\section{Differences in Perceptions Based on Demographic Factors}

To see if differences existed for demographic variables among students in the classes, analyses were run to determine differences in attitudes according to gender, business versus non-business majors, and student classification by year in school (second-year/sophomores, third-year/juniors, and fourth-year/seniors). Analysis showed no significant differences in gender or business and non-business students. However, significant differences resulted when the student classification was analyzed. Since there were only two second-year students in the data, these two observations were combined with third-year students. Then, second/third-year students were compared to fourth-year students. Table 4 shows the four areas of significant differences among fourth-year (senior) versus non-fourth-year (non-senior) students.

Table 3. Ratings of Specific Learning Unit Dimensions

\begin{tabular}{|c|c|c|c|c|c|}
\hline & \multicolumn{2}{|c|}{ Required Course } & \multicolumn{2}{|c|}{ Elective Course } & \multirow[b]{2}{*}{$\mathrm{p}$} \\
\hline & Mean & SD & Mean & SD & \\
\hline Ease of use & 3.37 & 1.01 & 4.15 & 0.91 & $.000 * * *$ \\
\hline $\begin{array}{l}\text { Clarity of } \\
\text { information }\end{array}$ & 3.69 & 0.84 & 4.15 & 0.71 & $.007 * *$ \\
\hline $\begin{array}{l}\text { Degree of interaction } \\
\text { with the user }\end{array}$ & 3.54 & 0.97 & 4.09 & 1.01 & $.010 *$ \\
\hline Interesting & 2.70 & 1.09 & 3.55 & 0.87 & $.000 * * *$ \\
\hline Useful & 3.24 & 1.00 & 3.94 & 0.83 & $.001 * *$ \\
\hline
\end{tabular}

The ratings shown are pooled measures for both online units, and are based on a five-point scale where: $5=$ excellent, $4=$ good, $3=$ satisfactory, $2=$ somewhat unsatisfactory, and $1=$ extremely unsatisfactory.

$\mathrm{p}<.05 ; * * \mathrm{p}<.01 ; * * * \mathrm{p}<.001$ 
Table 4. Significant Differences in Attitudes between $4^{\text {th }}$ Year (Senior) and Non- $4^{\text {th }}$ Year (Non-senior) Students

Usefulness of module 1

(high performance teams)

Clarity of info. in module 2

(communicating effectively)

Usefulness of module 2

(communicating effectively)

In the future an assignment similar

to this should be used in this

course.

$\begin{array}{cccc}\begin{array}{c}\text { Mean } \\ 4^{\text {th }} \text { Year } \\ \text { (Seniors) }\end{array} & \begin{array}{c}\text { Mean } \\ \text { Non } 4^{\text {th }} \text {-Year } \\ \text { (Non-seniors) }\end{array} & \mathrm{F} & \mathrm{p} \\ 3.73 & 3.09 & 5.58 & .022^{*} \\ 3.97 & 3.50 & 4.26 & .044^{*} \\ 3.70 & 3.00 & 7.02 & .011^{*} \\ 4.4 & 3.23 & 7.72 & .008^{* *}\end{array}$

Consistent with Table 3, the first three items above are based on a five-point response scale: $5=$ excellent, 4=good, $3=$ satisfactory, $2=$ somewhat unsatisfactory, and 1=extremely unsatisfactory.

Consistent with Table 2 , the last item above is based on the seven-point response scale: $7=$ strongly agree, $6=$ moderately agree, $5=$ slightly agree, $4=$ don't know/no opinion, $3=$ slightly disagree, $2=$ =moderately disagree, and $1=$ strongly disagree.

$* \mathrm{p}<.05 ; * * \mathrm{p}<.01 ; * * * \mathrm{p}<.001$

\section{Perceived Benefits of the Online Units}

In open-ended responses, participants expressed what they considered were the strengths of the online learning units. As shown in Table 5, the most commonly reported benefit of the online units, which was noted by more than one-third of the subjects (20 of 53), was the inclusion of simulations to apply concepts through exercises and user interaction. One participant commented, "The simulations are a valuable tool to gain experience with realistic environments." Another observed, "I liked the simulations because they allowed you to work through situations in a hands-on environment."

Sixteen participants cited the quality of the information and explanations presented in the unit. Seven users mentioned the flexibility and convenience of online learning, such as the ability to access the lessons anywhere at anytime, and to complete the units at one's own pace. Additional strengths reported included systems' ease of use, the organization of the units and immediate feedback, and the opportunity to gain online learning experience. One participant commented that the use of the online units offered "another learning perspective," and another said, "It gives you another way to learn instead of reading from a book."

\section{Problems and Limitations of the Online Units}

As indicated in Table 5, the open-ended responses about the problems and limitations of this experience are organized into three categories: content issues, technical issues, and issues involving the nature of this assignment. The most commonly reported content-related issue raised (by nine users) concerned the inclusion of simulations in the learning units. Some users disliked these exercises and/or reported that they took too much time. A few participants also stated that the online units did not contain enough "new" information or were not interesting.

Among technical issues, five users said they experienced problems losing previously completed (saved) work. A few others experienced problems registering at the MVU website or complained about the slowness of screen loads. Overall, the most commonly reported problem was the length 
of the assignment. More than 30 percent of the subjects (16 of 53) said that the online units were too long and required too much time to complete. One student commented, "Make the assignment shorter. The units were real time consuming." Another said that assigning "one online course probably would have been enough." A few other subjects stated that students should be given more time to complete the units or more detailed directions (see Table 5).

\section{Table 5. Perceived Strengths and Problems/Limitations of the Online Learning Units}

\begin{tabular}{lc} 
Perceived Strengths of Online Learning Units & $\begin{array}{l}\text { No. of users } \\
\text { mentioning * }\end{array}$ \\
\hline - Simulations: ability to apply concepts to realistic problem-solving & 20 \\
$\quad$ situations; good user interaction & 16 \\
- Content: quality of information and explanations presented; ability to & 7 \\
$\quad$ learn more about teams; units reinforced important concepts & 4 \\
- Flexibility, convenience, ability to complete units at own pace & 4 \\
- Ease of use & 3 \\
- Organization; quizzes at end of sub-units; ability for quick feedback &
\end{tabular}

\begin{tabular}{lc} 
Problems/Limitations of Online Learning Units & $\begin{array}{c}\text { No. of users } \\
\text { mentioning * }\end{array}$ \\
\hline $\begin{array}{l}\text { Content issues } \\
\text { - Online simulations: disliked doing; took too long; correct responses }\end{array}$ & 9 \\
$\quad$ were sometimes too similar to each other & 3 \\
- Online units not sufficiently interesting & 3 \\
- Online unit information not sufficiently "new”; of limited value & 5 \\
Technical issues & 3 \\
- Experienced problems with losing completed (saved) work & 2 \\
- Experienced problems registering or navigating at website & 16 \\
- Screen loads were too slow & 3 \\
$\begin{array}{l}\text { Assignment issues } \\
\text { - Online units were too long; required too much time }\end{array}$ & \\
- Students should be given more time to complete online units; don't \\
make both units due the same day; some underestimated completion \\
$\begin{array}{l}\text { time } \\
\text { - More detailed directions for online unit use should be given }\end{array}$ \\
* This indicates the number of participants who provided one or more of the responses shown in each re- \\
$\quad$ spective category. Some users' responses fit more than one category.
\end{tabular}

\section{Evaluation of the Classroom Component of the Online Learning Unit}

The classroom portion which followed the completion of the online modules was also evaluated in terms of both "quantity" and "quality." Most students (94 percent in the elective course and 79 percent in the required course) indicated that the amount of time devoted to class discussion of the learning units "was just about right." In addition, students in the elective course rated the classroom component significantly higher than students in the required course in terms of helping students to understand important concepts and in focusing attention on important points in the learning unit. About the online component of the course, one student commented that completing the units "reminded me how to act when I am in a group/team," and that, "in class I learned how others think of conflict." 


\section{Discussion}

This study provides data on an initial attempt to integrate online modules in a traditional class, moving toward the model of blended or online instruction. As indicated, only fair, or somewhat disappointing results were achieved, as participants in the elective course rated use of the learning modules slightly positive while students in the required course rated them slightly negative. This is not a compelling mandate for the use of or integration of e-learning or blended instruction. However, the results do raise important issues and provide insight about the implementation of online learning units in a traditional course. Perhaps the three most intriguing findings of the study involve the differences in respondents' attitudes toward the use of simulations in the online modules; differences in perceptions toward the online modules between those enrolled in the elective course versus those in the required course; and the apparent impact of the time required to complete the online modules on participants' perceptions of them.

As revealed in open-ended responses, while students identified the use of simulation as the leading strength of the online units, it was also the second most commonly mentioned problem of these units. Thus, the simulations tended to provoke strong emotions, being either "liked" or "disliked" by users. The simulations presented video cases about realistic problem-solving situations, pausing periodically to prompt users to make decisions about alternative courses of action.

The simulations were presented at the end of each online course, and they were designed to be integrative in nature, requiring the application of concepts learned throughout the course. Although some students viewed this as a challenge to test their understanding, others, who were less interested in the experience, were apparently anxious to complete the unit and less willing to work through these scenarios. An implication of this finding for course design is that when including simulation exercises, it may be more effective to intersperse several exercises in an online module than presenting a single simulation at the end.

Some of the participants, however, commented positively on the use of simulations to apply concepts to problem-solving situations and the content and quality of the information presented, confirming the value of the interactive nature of the instruction. Interestingly, students in the elective course rated the online modules more positively in terms of "overall satisfaction" and as "an effective way to learn" (as indicated by mean ratings of 5.67 out of 7 on both of these measures) than students in the required class. Similarly, older 4th-year students rated the modules as being more useful than 2nd- and 3rd-year students. These trends may relate to students' computer experience and attitudes toward technology.

A growing body of research suggests that computer users' prior experience with technology affects their attitudes about technology in general (Gefen, Karahanna \& Straub, 2003; Henry \& Stone, 1994; Martins \& Kellermanns, 2004; Stoel \& Lee, 2003; Wober \& Gretzel, 2000). The greater amount of experience users have with technology the higher the levels of users' satisfaction in learning to use new technology (Simmers \& Anandarajan, 2001; Volery \& Lord, 2000). Having experienced an online learning unit in a blended context may likely benefit students in the future as they make decisions about selecting between different educational or training options for themselves or those they manage. The results may suggest that students with more experience with technology and e-learning rate it more positively.

Another notable finding of this study is that students in the elective course consistently rated the use of the online learning components more favorably than those in the required course. As presented in Tables 2 and 3, participants in the elective course rated both the online and the classroom portions of learning more favorably than students in the required course on almost every measure. 
These results are consistent with research that shows that students exhibit greater motivation when course content interests them and when they perceive some personal relevance with the content (Adler, Milne \& Stablein, 2001; Benbunan-Fich \& Starr, 2003; Brass, 2002; Burke \& Moore, 2003; Geiger \& Cooper, 1996), which may account for why students in the elective course were more positive in their attitudes than those enrolled in required courses. The elective class also had more 4th-year students than the required classes; the 4th-year students rated several of the dimensions higher than the 2nd- and 3rd-year students. The higher ratings by the 4th-year students may suggest they had more technological experience than the younger students and that they were more independent learners. This outcome suggests that if online instruction requires a significant investment of time (that is several hours or more), it is more likely to be accepted by students in an elective course than a required one and by students with more technology experience than less.

A key consideration about online learning that seems to have emerged in this study is the completion time required for the online modules. Most students simply did not feel that the amount of time it took to complete the modules was worth what was gained, as reflected in Table 2. More than 30 percent of participants in the open-ended responses commented that the completion of the online units required too much time. On average, users needed nearly eight hours to finish the two learning units in their entirety, and this appears to be a greater investment of time than most students were willing to make. The online courses were self-paced, independent study units. For most participants, who were accustomed to learning in a traditional, face-to-face classroom environment and who had little experience with online learning, the completion of the online units may have seemed like a lengthy, solitary experience.

It is quite likely that students' perceptions of this experience would have been more favorable if shorter online units were utilized, if the two modules had been spread over a longer period of time, or if only one of the two learning units had been required. This research outcome suggests that other educators who integrate e-learning into traditional courses may want to select small, fairly easy to complete segments of online material rather than lengthy online units that take several hours - at least in the beginning and with students who have limited experience with elearning.

Finally, we should note that an issue related to the scales used in this study may have affected the results. As noted earlier, seven-point scales were used for most of the opinion items in the survey that addressed satisfaction or agreement/disagreement. This scale used a mid-point of "don't know/no opinion." In retrospect, it would have been more appropriate to word the mid-point "neutral" or "neither agree/disagree" to capture the opinions of respondents more accurately, since an opinion "don't know" is not necessarily an indication of an opinion between "slightly agree" and "slightly disagree." The terminology used may have led to some unintended bias of the data, either negatively or positively, since survey participants with little energy or empathy for the survey who marked "don't know/no opinion" may not have been accurately responding between slightly satisfied and slightly dissatisfied.

\section{Conclusion}

At first glance, the only fair results of this study may cause some readers to question the value of incorporating online learning units into a traditional course. The ultimate question for educational research is how to optimize instructional designs and technology to maximize learning opportunities and achievements in both online and face-to-face environments. Specifically, the conditions for best promoting online success have not yet been fully explicated.

One important benefit of these online modules was that it provided most students with their first experience using e-learning. Fewer than 4 percent of participants had prior experience completing 
an online course at the MVU website, and only 17 percent had completed an online course at another site. As the use of e-learning grows rapidly in business and industry, increasingly new college graduates will be expected to learn on the job in an online environment. Through this project, students gained experience with e-learning, experience which may help them to be more effective using it in the future.

Further research can continue to explore how and when online instruction is most effective. For instance, additional investigation should look at motivational factors affecting students in taking elective and required courses in traditional, online, and blended approaches to instruction, along with students' computer experience related to satisfaction with online instruction.

From a broader perspective, a comprehensive report issued by the Commission on Behavioral and Social Sciences and Education of the National Research Council has underscored the growing importance of technology to education and the need for more research to better understand its application. According to this commission (Bransford, Brown \& Cocking 2000, p. 194):

Because many new technologies are interactive, it is now easier to create environments in which students can learn by doing, receive feedback, and continually refine their understanding and build new knowledge. . . . Computer-based technologies hold great promise both for increasing access to knowledge and as a means of promoting learning. . . . Much remains to be learned about using technology's potential: to make this happen, learning research will need to become the constant companion of software development.

E-learning represents an important, growing trend in the application of technology to facilitate student learning - especially in colleges where programs and curricula must evolve to meet the changing needs of a competitive global economy (Richardson, 2003). The study presented here focuses on students' perceptions of online learning modules using self-paced, independent study learning units among users with mostly limited prior e-learning experience. The findings provide important insight about users' perceptions of e-learning and raise practical considerations for its implementation. However, this study involves the use of e-learning in only one setting, whereas there are many other ways to implement this concept. Researchers are encouraged to investigate e-learning using other types of subjects, online learning technologies, courses, and with blended learning designs.

One prospect for future research is to compare student learning outcomes between classes using a blended learning approach versus those using traditional instruction. Another possibility is to examine user perceptions of online learning modules where the online learning units are considerably shorter in length than those employed in this study. This approach would likely reduce the "fatigue factor" apparently experienced by some participants and result in greater user satisfaction. Additionally, research could explore which types of e-learning components-synchronous chat, asynchronous discussion postings, email, simulations, and so forth-are most effective in terms of learner satisfaction and in achieving desired student learning outcomes.

Furthermore, as students become more experienced in online instruction, their attitudes toward elearning and blended approaches may change. Complementary research can explore issues of familiarity and technical skill related to successful e-learning experiences. Overall, further research will likely yield additional insight to educators and trainers about where, when, and how to apply e-learning and blended learning most effectively to meet the evolving needs of individuals both in school and in the workplace.

This research was not about assessing the difference between online vs. face-to-face instruction; rather, this research is more about how we can use technology effectively in the classroom and how students react to it. Technologies as used in online and blended learning situations have the potential to enrich the learning experience, to do more than what can be done in face-to-face or 
other approaches. The results from this study provide clues in how online components and strategies might be implemented to enhance teaching and learning in the $21^{\text {st }}$ century, specifically as we work to engage students actively in learning, to provide real-world contexts for learning, and to promote critical thinking and deep learning.

\section{References}

Adler, R. W., Milne, M. J. \& Stablein, R.. (2001). Situated motivation: An empirical test in an accounting class. Canadian Journal of Administrative Sciences, 18(2), 101-116.

Ancona, D. G., \& Caldwell, D. F. (1992). Demography and design predictors of new product team performance. Organization Science, 3, 321-341.

Beller, M. \& Or, E. (1998). The crossroads between lifelong learning and information technology: A challenge facing leading universities. Journal of Computer-Mediated Communication (online journal), 4(2) (December). Retrieved 16 May 2006 from http://jcmc.indiana.edu/vol4/issue2/beller.html

Benbunan-Fich, R. \& Starr, R. H. (2003). Mediators of the effectiveness of online courses. IEEE Transactions on Professional Communication, 46(4), 296-312.

Benek-Rivera, J., \& Matthews, V.E. (2004). Active learning with jeopardy: Students ask the questions. Journal of Management Education, 28, 104-118.

Bereiter, C., \& Scardamalia, M. (1989). Intentional learning as a goal of instruction. In L.B. Resnick (Ed.), Knowing, Learning, and Instruction (p. 361-392). Hillsdale, NJ: Erlbaum.

Bonwell, C.C., \& Eisen, J.A. (1991). Active learning: Creating excitement in the classroom (ASHE-ERIC Higher Education Report No. 1). Washington, DC: George Washington University.

Bransford, J. D., Brown, A. L., \& Cocking, R. R. (Eds.). (2000). How people learn: Brain, mind experience, and school committee on developments in the science of learning. Commission on Behavioral and Social Sciences and Education of the National Research Council, National Academy Press.

Brass, K. (2002). Pushing E-learning. Sales and Marketing Management, 154(3), 56.

Brown, K. M. (1996). The role of internal and external factors in the discontinuation of off-campus students. Distance Education, 17(1), 44-71.

Burke, L. A. \& Moore, J. E. (2003). A perennial dilemma in OB education: Engaging the traditional student. Academy of Management Learning \& Education, 2(1), 37-53.

Cole, M. S., Field, H. S. \& Harris, S. G. (2004). Student learning motivation and psychological hardiness: Interactive effects on students' reactions to a management class. Academy of Management Learning \& Education, 3(1), 64-85.

Davis, J. (2000). Traditional vs. online learning: It's not an either/or proposition. Employment Relations Today, 27(1), 47-60.

Driscoll, M. (2002). How people learn (and what technology might have to do with it). ERIC Clearinghouse on Information and Technology Syracuse, NY. Retrieved 5 January 2006 from http://www.ericdigests.org/2003-3/learn.htm

Driscoll, M. \& Carliner, S. (2005). Advanced web-based training strategies. San Francisco: Pfeiffer.

Duffy, T. M., \& Cunningham, D. J. (1996). Constructivism: Implications for the design and delivery of instruction. In D. H. Jonassen (Ed.), Handbook of research for educational communications and technology. New York: Macmillan.

Eble, K. (1994). Craft of teaching: A guide to mastering the professor's art ( $2^{\text {nd }}$ edition), New York: Jossey-Bass.

E-learning replaces classroom. (2003). Health Management Technology, 24(4), 50-51.

Frankola, K. (2001). Why online learners drop out. Workforce, 10, 52-60. 
Gefen, D., Karahanna, E. \& Straub, D. W. (2003). Inexperience and experience with online stores: The importance of TAM and trust. IEEE Transactions on Engineering Management, 50(3), 307-321.

Geiger, M. A. \& Cooper, E. A. (1996). Using expectancy theory to assess student motivation. Issues in Accounting Education, 11(1), 113-125.

Gold, M. (2003). IRS goes E. $T+D$, 57(5), 76-82. [Please clarify the name of this journal. It is $T+D$ ?]

Golladay, R., Prybutok, V. \& Huff, R. (2000). Critical success factors for the online learner. Journal of Computer Information Systems, 40(4), 69-71.

Gruenfeld, D. H., \& Hollingshead, A. B. (1993). Sociocognition in work groups: The evolution of group integrative complexity and its relation to task performance. Small Group Research, 24(3), 383-405.

Hackman, J. R. (Ed.) (1990). Groups that work (and those that don't). San Francisco: Jossey-Bass.

Hall, B. (2003). FAQs about e-learning. Retrieved August 15, 2003, from www.brandonhall.com/public/faqs $2 /$ faqs $2 . \mathrm{htm}$

Hara, N. \& Kling, R. (2000). Students' distress with a web-based distance education course: An ethnographic study of participants' experiences. Information, Communication and Society, 3(4), 557-579.

Haugen, S., LaBarre, J., \& Melrose, J. (2001). Online course delivery: Issues and challenges. Issues in Information Systems, 2, 127-131.

Henry, J. W. \& Stone, R. W. (1994). A structural equation model of end-user satisfaction with a computerbased medical information system. Information Resources Management Journal, 7(3), 21-34.

Honebein, P. C. (1996). Seven goals for the design of constructivist learning environments. In B. G. Wilson (Ed.), Constructivist learning environments: Case studies in instructional design. Englewood Cliffs, NJ: Educational Technology Publications.

Johnston, J., Killion, J., \& Oomen, J. (2005). Student satisfaction in the virtual classroom. The Internet Journal of Allied Health Sciences and Practice. 3. Available January 26, 2006, at http://ijahsp.nova.edu/articles/vol3num2/Johnston\%20-\%20Printer\%20Version.pdf

Koohang, A. \& Durante, A. (2003). Learners' perceptions toward the web-based distance learning activities/assignments portion of an undergraduate hybrid instructional model. Journal of Informational Technology Education 2, 105-113. Available at http://jite.org/documents/Vol2/v2p105-113-78.pdf

Koprowski, G. (2000). Online learning: The competitive edge. Informationweek (August 28), 124-128.

Laine, L. (2003). Is e-learning effective for IT training? $T+D$, 57(6), 55-60.

Liaw, S. \& Huang, H. (2002). How web technology can facilitate learning. Information Systems Management, (Winter), 56-61.

Martins, L. L. \& Kellermanns, F. W. (2004). A model of business school students' acceptance of a webbased course management system. Academy of Management Learning \& Education, 3(1), 7-39.

McDonald, D. (1999-2000). Improved training methods through the use of multimedia technology. Journal of Computer Information Systems, 40(2), 17-20.

McEwan, B. (2001). Web-assisted and online learning. Business Communications Quarterly, 64(2), 98103.

McEwen, T. (1997). Communication training in corporate settings: Lessons and opportunities for the academe. Mid-American Journal of Business, 12(1), 49-58.

McKeachie, W. (2002). McKeachie's Teaching Tips: Strategies, Research, and Theory for College and University Teachers (11th ed.). Boston, MA: Houghton Mifflin.

Meyen, E.L., Aust, R., Gauch, J.M., Hinton, H.S., \& Isaacson, R.E.. (2002). e-Learning: A programmatic research construct for the future. Journal of Special Education Technology. Retrieved December 28, 2005, from http://jset.unlv.edu/17.3/smith/smith.pdf 
Miller, R.A. \& Luse, D.W. (2004). Advancing the IS curricula: The identification of important communication skills needed by IS staff during systems development. Journal of Informational Technology Education, 3, 117-131. Available at http://jite.org/documents/Vol3/v3p117-131-107.pdf

Moore, C. (2001). E-learning leaps into the limelight. InfoWorld, 23(5), 32.

O’Neill, K., Singh, G. \& O’Donoghue, J. (2004). Implementing elearning programmes for higher education: A review of the literature. Journal of Informational Technology Education, 3, 313-323. Available at http://jite.org/documents/Vol3/v3p313-323-131.pdf

Pallof, R., \& Pratt, K. (2003). The Virtual Student: A Profile and Guide to Working with Online Learners. San Francisco, CA: Josey-Bass Publishers.

The pay-offs of e-learning go far beyond the financial. (2003). HR Focus, 80(10), 7-9.

Picciano, A.G. (2002). Beyond student perceptions: Issues interaction, presence, and performance in an online course. Journal of Asynchronous Learning Networks, 6, 20-41.

Piccoli, G., Ahmad, R. \& Ives, B. (2001). Web-based virtual learning environments: A research framework and a preliminary assessment of effectiveness in basic IT skills training. MIS Quarterly, 25(4), 401425.

Quitadamo, I.J. \& Brown, A. (2001). Effective teaching styles and instructional design for online learning environments. National Educational Computing Conference, July 25-27, 2001 (Chicago, IL). Retrieved January 10, 2006 at http://confreg.uoregon.edu/NECC2001/program/research_pdf/Quitadamo.pdf

Richardson, L. (2003). A challenge to change business education. Mid-American Journal of Business, $18(1), 5-6$.

Rubenstein, H. (2003). Recognizing e-learning's potential \& pitfalls. Learning \& Training Innovation,s $4(4), 38$.

Ryan, S. (2001). Is online learning right for you? American Agent \& Broker, 73(6), 54-58.

Sarason, Y. \& Banbury, C. 2004. Active learning facilitated by using a game-show format or who doesn't. Journal of Management Education; 28 (4), 509-518.

Scardamalia, M. (2002, April). Creative work with ideas: A luxury? Paper presented at the annual meeting of the American Psychological Association, New Orleans, LA.

Scheidel, T. M. \& Crowell, L. (1979). Discussing and decoding: A deskbook for group leaders and members. New York: Macmillan.

Schleede, J. (1998). The best of times or the worst of times for business education? Mid-American Journal of Business, 13(1), 4-5.

Scriven, M. \& Paul, R. (2004). Defining critical thinking. Available online January 26, 2006, at http://www.criticalthinking.org/aboutCT/definingCT.shtml

Serwatka, J. (2003). Assessment in on-line CIS courses. Journal of Computer Information Systems, 43(3), $16-20$.

Simmers, C. A. \& Anandarajan, M. (2001). User satisfaction in the Internet-anchored workplace: An exploratory study. Journal of Information Technology, Theory, and Application, 3(5), 39-62.

Stoel, L. \& Lee, K. H.. (2003). Modeling the effect of experience on student acceptance of Web-based courseware. Internet Research, 13(5), 364-374.

Tuckman, B.W. (1965). Developmental sequence in small groups. Psychological Bulletin, 63, 384-99.

Volery, T. \& Lord, D. (2000). Critical success factors in online education. The International Journal of Education Management, 14(5), 216-223.

Wang, Y. (2003). Assessment of learner satisfaction with asynchronous electronic learning systems. Information \& Management, 4l(1), 75-86. 
Ward, J. \& LaBranche, G. (2003). Blended learning: The convergence of e-learning and meetings. Franchising World, 35(4), 22-23.

Watkins, R. (2005). Developing interactive e-learning activities. Performance Improvement, 44, 5-7.

Watson, W. Kumar, E., K. \& Michaelsen, L. K. (1993). Cultural diversity's impact on interaction process and performance: Comparing homogenous and diverse task groups. Academy of Management Journal, $36,590-602$.

Wober, K. \& Gretzel, U. (2000). Tourism managers' adoption of marketing decision support systems. Journal of Travel Research, 39(2), 172-182.

\section{Biographies}

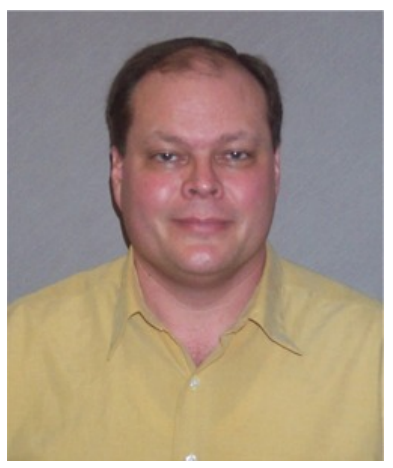

Karl L. Smart, Ph.D., an Associate Professor of Business Information Systems at Central Michigan University, teaches a variety of undergraduate and graduate courses, including courses in business communication, computer graphics, and business teacher education. Dr. Smart's research and publications have focused on user-centered design, issues of quality in communication, and learning styles and teaching effectiveness. Prior to his academic appointment, he spent several years working in the software industry. He holds degrees from the University of Utah, Utah State University, and the University of Florida.

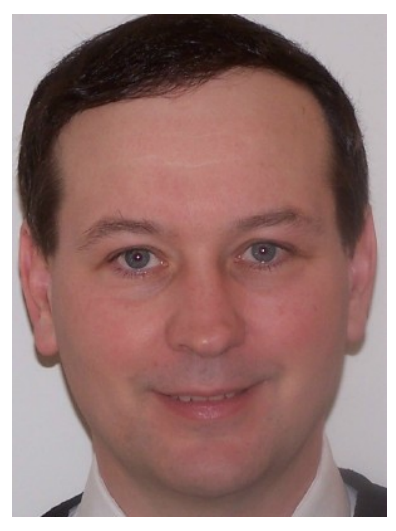

James J. Cappel, Ph.D., is an Associate Professor of Business Information Systems at Central Michigan University in Mt. Pleasant, Michigan. He teaches undergraduate and graduate courses in Management Information Systems (MIS). Dr. Cappel has published forty refereed journal articles and serial publications, and he regularly makes presentations at professional conferences. His research areas include MIS pedagogical issues, web design/usability, and business intelligence. Dr. Cappel was awarded the Faculty Adviser of the Year Award by the Association of Information Technology Professionals (AITP) for 2002-2003. He holds a B.A. from Xavier University in Cincinnati, and M.S. and Ph.D. degrees from the University of North Texas. 